\title{
Rethinking the concept of failed state Ilona SZUHAI
}

\author{
Bevándorlási és Állampolgársági Tanszék, Rendészettudományi kar, Nemzeti Közszolgálati Egyetem \\ Department of Immigration and Nationality, Faculty of Law Enforcement, National University of Public \\ Service \\ 12 Farkasvölgyi Street, H-1121 Budapest, Hungary \\ Szuhai.llona@uni-nke.hu
}

"State failure is largely man made, not accidental."

Robert I. Rotberg

\section{Introduction}

In the course of studying the global humanitarian crises and the mass refugee movements, dealing with the concept of failed states is unavoidable. Based on the relevant literature, this study summarises the history of failed state concept, the difficulties of a clear definition of failed state and the reasons why various linking expressions like weak, fragile, failing, collapsed states are mixing. Clarification of the concept has key importance due to its measurement, as well as, the possible alternatives for a clear definition. As Patrick Stewart has noted, "poorly performing developing countries are linked to humanitarian catastrophes; mass migration; environmental degradation; regional instability; energy insecurity; global pandemics; international crime; the proliferation of weapons of mass destruction (WMD); and, of course, transnational terrorism. ${ }^{11}$ Instability in governance and intrastate armed conflicts promote humanitarian crises and misery. All of those generate one of the biggest global phenomena today, the mass movements of refugees. 2015 remained a turbulent year of conflicts which drew attention on failed states. With a special view on Iraq, the study concentrates on a form of forced migration when people leave their home due to intrastate armed conflicts, terrorist activities, brutal violation of human rights, poverty, lack of humanitarian aid and poor public services. It outlines the connection with security and one of the biggest actual global phenomena, the mass refugee movements. That has become in the focus of the European discourse due to the humanitarian catastrophe in the Mediterranean. The current measurement of instable states is problematic which has strong impact on interventions and aid operations.

\section{History of failed state concept}

In the history of the concept, Charles Call pointed out that two early works, Helman and Ratner's 1993 'Failed States' article in Foreign Policy and Zartman's Collapsed States in

1 STEWART, Patrick: Weak States and Global Threats: Fact or Fiction? in: The Washington Quarterly, 29, 2006, 2, 27. 
1995, addressed the most prominent crises of the early 1990s. Helman and Ratner referred to states that are simply unable to function as independent entities. Zartman's collapsed states where the basic functions of the state are no longer performed. ${ }^{2}$ Zartman develops a wider idea of state failure that draws on Hobbesian social contract theory. Michael Ignatieff adopts a Machiavellian/Weberian understanding of state failure when he argues that state failure occurs when "the central government loses the monopoly of the means of violence". Rotberg defines that "nation-state fail because they are convulsed by international violence and can no longer deliver positive political goods to their inhabitants. ${ }^{\prime 3}$ There are many categories and definitions of state failure that have proliferated in the literature. State failure can occur in many dimensions such as security, economic development, political representation, income distribution and so on. ${ }^{4}$

It could be summarized that "how one defines the state will determine how one understands state failure". In international law, a given state is often said to exist when a political entity is recognised by other states as the highest political authority in a given territory and is treated as an equal among the international community of states. Statehood does not require diplomatic recognition by other states, but rather a recognition that it exists. Another popular definition in international customary law says that statehood exists only when a given political entity possesses a permanent population, a defined territory, a government, and the capacity to enter into relations with the other states. This definition suggests that statehood is independent of recognition by other states. However, the state can also be defined in terms of its internal political characteristics, particularly its domestic authority and legitimacy. This means that even if a given political entity is recognised as a state under international law, it cannot be considered a state unless certain domestic political conditions are met. ${ }^{5}$ Zartman's answer to the question: Why do states collapse? "Because they can no longer perform the functions required for them to pass as states. A state is authoritative political institution that is sovereign over a recognized territory." ${ }^{6}$ Even for weaker states - whose domestic structures have been influenced by outside actors, and whose leaders have very little control over transborder movements or even activities within their own country - sovereignty remains attractive. ${ }^{7}$ Krasner distinguishes four different meanings of sovereignty: interdependence sovereignty, domestic sovereignty, Westphalian or Vattelian sovereignty, and international legal sovereignty. ${ }^{8}$ I point out the interdependence sovereignty as it refers to the ability of states to control movement across their borders. The right of states to manage their borders is not challenged, but globalization, it is assert-

2 CALL, Charles T.: The Fallacy of the Failed State, in: Third World Quarterly, 29, 2008, 8, 1492.

3 ROTBERG, Robert I.: Failed States, Collapsed States, Weak States: Causes and Indicators, in: State Failure and State Weakness in a Time of Terror, ROTBERG, Robert I. (ed.), Washington 2003, 1.

4 DI JOHN, Jonathan: The Concept, Causes and Consequences of Failed States: A Critical Review of the Literature and Agenda for Research with Specific Reference to Sub-Saharan Africa, in: European Journal of Development Research, 22, 2010, 1, 13.

5 NGUYEN, Minh: The question of 'failed states', Australia and the Notion of State Failure, in: View on Asia, 2005, 4, online: http://www.uniya.org/research/state_failure.pdf.

6 ZARTMAN, William I.: Introduction: Posing the Problem of State Collapse, in: Collapsed States: The Disintegration and Restoration of Legitimate Authority, ZARTMAN, William I. (ed.), Boulder 1995, 5.

7 KRASNER, Stephen D.: Sovereignty, in: Foreign Policy, no. 122, 2001, 20.

8 KRASNER, Stephen D.: Abiding Sovereignty, in: International Political Science Review, 22, $2001,3,231$. 
ed, has eroded their ability to actually do so. ${ }^{9}$

According to Di John's summary, "the literature on state failure has two main strands. The first is the view that a failing state contains a set of institutional structures that deviate from a modern Weberian bureaucracy. The second view, represented by the so-called functionalist theories, argues that it is pointless to measure failure." 10 It is worth adding that according to Acemoglu and Robinson, the wellbeing of nations depends on the institutional structures. The politics and political institutions determine the economic institutional system, i.e. how effective the state is. If the economy is stable and inclusive, it stimulates the economic development that means prosperity. If the economy is extractive that gives barriers to development. ${ }^{11}$

\section{Critics and problem with definition and measurement}

The concept has been criticized on theoretical, normative, empirical and practical grounds. ${ }^{12}$ The most serious problem with the concept of failed states is the problem of definition, and more specifically of super-aggregation of very diverse sorts of states and their problems. However, the 'failed state' concept now clouds, even misleads, clear analysis. Its utility is diminished for a number of reasons. The concept contains culturally specific assumptions about what a 'successful' state should look like and groups together disparate sorts of states with diverse problems. The failed state idea also leads to narrow and univalent policy prescriptions that obscure other important conceptual issues and practical challenges. ${ }^{13}$

The world of contemporary global politics is rich in cases of concepts that are ambiguous and employed by scientists and policymakers alike. The concept of failed states is just one of these. ${ }^{14}$ The failed states concept - and related terms like 'failing', 'fragile', 'stressed' and 'troubled' states - has become more of a liability than an asset. The term ,failing state' has grown to encompass states as diverse as Colombia, East Timor, Indonesia, North Korea, Cote d'Ivoire, Haiti, Iraq, and the Sudan. This confirms the excessive aggregation of diverse states. Despite having made the most serious attempt to develop criteria to distinguish 'failing', 'failed' and 'collapsed' states, Zartman, Rotberg, and some policy-oriented projects have had difficulties developing indicators that are intuitively logical or widely shared. The concept of failed state has also enhanced the linkage not just between international security and internal stability among poor, peripheral societies, but also that between basic freedoms and service delivery within small, powerless societies and the

\footnotetext{
9 Ibidem.

10 Di JOHN, Jonathan: Conceptualising the Causes and Consequences of Failed States, A Critical Review of the Literature, in: Crisis States Working Paper, Series 2, no. 25, 2008, 25.

11 ACEMOGLU, Daron - ROBINSON, James A.: Why nations fail: The origins of power, prosperity, and poverty, New York 2012, 76.

12 EZROW, Natasha - FRANTZ, Erica: Revisiting the Concept of the Failed State: bringing the state back, in: Third World Quarterly, 34, 2013, 8, 1323.

13 CALL, 1494.

14 BUEGER, Christian - BETHKE, Felix: Actor-networking the ,failed state' - an enquiry into the life of concepts, in: Journal of International Relations and Development, 17, 2014, 1, 52.
} 


\begin{tabular}{c|ccc}
\hline \\
0
\end{tabular}

interests of Western powers and regional powers. ${ }^{15}$ Mazarr has explained that a lack of definitional rigor posed a second problem that there has never been a coherent set of factors that define failed states. ${ }^{16}$ The most prominent example of efforts to measure the phenomenon is the so-called Failed States Index, published annually by the non-profit organisation Fund for Peace since 2005. The Failed States Index presents a diagnosis of the problem, the first step in devising strategies for strengthening weak and failing states. In 2013, the name of the Failed States Index changed to the Fragile States Index. ${ }^{17}$ While the methodology remains the same, the new title is an acknowledgment that all states, to different degrees, face conditions that threaten the livelihoods of their citizens. ${ }^{18}$ The current measurement of instable states is problematic which has strong impact on interventions and aid operations. ${ }^{19}$ That is why the question defines by Rotberg has key importance: "who shall make the judgement?" 20 As clarification of the concept and the use of the term have consequences, therefore, it is worth pointing out Rotberg's three important signals of impending failure. ${ }^{21}$ The economic and political indicators and the level of violence provide clearer, more timely and more actionable warnings. Regarding the economic indicator, reductions in incomes and living standards indicate the possibility of failure early enough to be noted and for preventive measures. Once the downward spiral starts in earnest, only a concerted, determined effort can slow its momentum; corrupt autocrats and their equally corrupt associates usually have few incentives to arrest their state's slide, since they find clever ways to benefit from impoverishment and misery. The available political indicators are equally clear, if somewhat less quantifiably precise. "A leader and his associates begin by subverting democratic norms, greatly restricting participatory processes, and coercing a legislature and the bureaucracy into subservience. They end judicial independence, block civil society, and suborn the security forces. Political goods become scarce or are supplied to the leading class only. The rulers demonstrate more and more contempt for their peoples, surround themselves with family, clan, or ethnic allies, and distance themselves from their subjects. The state becomes equated in the eyes of most citizens with the particular drives and desires of a leader and a smallish group. Many of these leaders drive grandly down their boulevards in motorcades, commandeer commercial aircraft for foreign excursions, and put their faces prominently on the local currency, on airports and ships, and on oversize photographs in public places." 22 "The third indicator is the level of violence. If it rises precipitously because of skirmishes, hostilities, or outright civil war, the state can be considered crumbling. As national human security rates fall, the probability of failure rises.

15 CALL, 1491.

16 MAZARR, Michael J.: The Rise and Fall of the Failed-State Paradigm, in: Foreign Affairs, 93, 2014, 1, online: http://www.foreignaffairs.com/articles/140347/michael-j-mazarr/the-rise-and-fall-of-the-failed-state-paradigm.

17 Fragile State Index, online: http://ffp.statesindex.org.

18 Fragile State Index, 2013.

19 Acemoglu and Robinson noted that aid actions do not give solutions as the root of the problem is the political and economic institution system. Additionally, significant portion of international aids does not reach the target groups.

20 ROTBERG, Robert I.: Failed States in a World of Terror, in: Foreign Affairs, 81, 2002, 4, 1.

21 ROTBERG, 2003, 21.

22 Ibidem. 
Not every civil conflict precipitates failure, but each offers a warning sign. Absolute or relative crime rates and civilian combat death counts above a certain number cannot prescribe failure. But they show that a society is deteriorating and that the glue that binds a new (or an old) state together is becoming fatally thin." ${ }^{23}$

"No single indicator provides certain evidence that a strong state is becoming weak or a weak state is heading pell-mell into failure. But a judicious assessment of the several available indicators discussed in this section, taken together, should provide both quantifiable and qualitative warnings. Then avoidance maneuvers can occur and efforts at prevention can be mounted." 24

These indicators verify Rotberg's statement that "state failure is largely man made, not accidental." 25

\section{Rethinking the concept of failed state}

The institutions of the state play a critical role in affecting development and stability. Ezrow and Frantz argue that exploring how specific types of institutions affect political stability and economic performance (and vice versa) provides greater analytical leverage than is currently offered by the 'failed states' literature. This is more useful than looking at the challenges faced by the developing world and assuming that the state is somehow linked to them. A narrower focus should improve our efforts to better understand the ways in which institutions are important in causing and preventing these problems and how the international community can help to fortify institutions before the major signs of 'failure' have taken place ${ }^{26}$ Call suggests as alternatives: Collapsed states; Weak formal institutional capacity (aka 'weak states'); War-torn states; Authoritarian states/regimes.

Another alternative may be the 'crises states'. The Crisis States Research Centre decided to focus on 'crisis states', since they wanted to investigate the processes that led states to collapse into violence and war or to recover from episodes of extreme violence - that is, 'states in crisis' - and they wanted to examine how communities at the local and national level in poor countries coped with severe internal and external shocks - or 'conditions of crisis' - and managed to avoid violence. ${ }^{27}$

Policy practice directed towards 'fragile states' has been confounded by a failure to make clear what distinguishes the particular problem of 'fragility' from general problems facing all developing countries. An important conceptual innovation by the Crisis States Research Centre is that its definition of state fragility directs attention to factors that are most likely to provoke violence and lead towards state collapse: the lack of a basic legitimate monopoly over the means of large-scale violence, the absence of control over taxation, the failure of state organisations to operate in significant territories of the country and the existence of rival rule systems that take precedence over the state's rules. There is clearly a category

23 Ibidem, 22.

24 Ibidem.

25 Ibidem.

26 EZROW - FRANTZ, 1335.

27 PUTZEL, James - Di JOHN, Jonathan: Meeting the challenges of Crisis States. Crisis States Research Centre report, London 2012, ii. 


\begin{tabular}{|c|c|c|}
\hline $\operatorname{cov}$ & 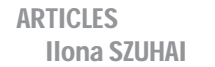 & 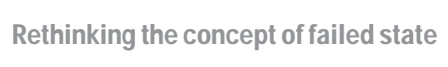 \\
\hline
\end{tabular}

of 'resilient states' among the least developed countries, which has not been given due recognition in theory or policy practice. ${ }^{28}$

According to Mazarr, "although interconnectedness and interdependence may create risks, the dangers in such a world are more likely to come from strong, well-governed states with imperfect regulations than weak ones with governance deficiencies. Financial volatility that can shake the foundations of leading nations and cyberattacks that could destabilize energy or information networks pose more immediate and persistent risks than, say, terrorism". 29

\section{Link between the concept of failed state and security}

As Michael Ignatieff has stated, the collapse of many former colonial states resulted in a vacuum of chaos and massacre into which a new imperialism has reluctantly stepped reluctantly because these places are dangerous and because they seemed, at least until 11 September, to be marginal to the interests of the powers concerned. But, gradually, this reluctance has been replaced by an understanding of why order needs to be brought to these places. ${ }^{30}$ The attacks of 9/11 focused attention on the failure of the Afghan state to prevent the operation of al-Qaeda on its territory. The situation in that country, and subsequent growing concern about other similar states, only intensified concern about the role of 'failed states' in harbouring or aiding terrorism. The US National Security Strategy of 2002 marked this shift ${ }^{31}$ from the battlefields of Europe: "America is now threatened less by conquering states than by failing ones". This policy direction was reinforced by the Obama administration, which, in its 2010 National Security Strategy, called for a renewal of U.S. leadership in "secur[ing] fragile states like Afghanistan and Haiti." The United States was not alone in its concern over the potential that failed states could sow discord far beyond their borders. ${ }^{32}$ Similarly, the European Security Strategy of 2003 also sounded among regional problems that "conflict can lead to extremism, terrorism and state failure; it provides opportunities for organised crime." According to the Strategy, the "state failure: bad governance - corruption, abuse of power, weak institutions and lack of accountability - and civil conflict corrode states from within. In some cases, this has brought about the collapse of State institutions. Somalia, Liberia and Afghanistan under the Taliban are the best known recent examples. Collapse of the state can be associated with obvious threats, such as organised crime or terrorism. State failure is an alarming phenomenon that undermines global governance, and adds to regional instability." Further on, "neighbours who are engaged in violent conflict, weak states where organised crime flourishes, dysfunctional societies or exploding population growth on its borders all pose problems for Europe." As Fukuyama stated, "the chief threats to us and to world order come from weak, collapsed,

28 PUTZEL - Di JOHN, v.

29 MAZARR

30 IGNATIEFF, Michael: The Burden, in: The New York Times, January 5, 2003. Online: http://www.nytimes. com/2003/01/05/magazine/05EMPIRE.html?pagewanted=all.

31 CALL, 1491.

32 SEDRA, Mark: Finding Innovation in State-Building: Moving Beyond the Orthodox Liberal Model, in: Prism, $3,2012,3,47$. 
or failed states. Weak or absent government institutions in developing countries form the thread linking terrorism, refugees, AIDS, and global poverty." The security aspect reflects in definitions. ${ }^{33}$ Hout $^{34}$ notes that "fragile states came to be seen as a potential incubator of state collapse, which would result in the creation of 'ungoverned spaces', where crime and terrorism could develop." Security, according to Rotberg, is a key indicator: failed states typically endure widespread violence against the existing regime, conflict between communities within the state, an inability to control territory and borders, the growth of criminal violence and a tendency by the authorities to "prey on their own constituents". Failed states are also characterized by weak institutions, the absence of the rule of law, a highly politicized military and a deteriorating or destroyed infrastructure. ${ }^{35}$ The acceptance or recognition of a given authority structure is one aspect of domestic sovereignty; the other is the level of control that officials can actually exercise. This has varied dramatically. Well-ordered domestic policies have both legitimate and effective authority structures. Failed states have neither. The loss of interdependence sovereignty, which is purely a matter of control, would also imply some loss of domestic sovereignty, at least domestic sovereignty understood as control, since if a state cannot regulate movements across its borders, such as the flow of illegal drugs, it is not likely to be able to control activities within its borders, such as the use of these drugs. ${ }^{36}$

\section{The global understanding the concept of failed state}

With the Global War on Terror emerging as a new major strategic narrative, the scale of the concept of failed state now became even more explicitly global. ${ }^{37}$ Iraq represents the first in a series of struggles to contain the proliferation of weapons of mass destruction, the first attempt to shut off the potential supply of lethal technologies to a global terrorist network. ${ }^{38}$ The frequency and intensity of U.S. and international nation-building efforts have increased since the end of the Cold War, which, as Michael Ignatieff has pointed out, left a band of weak or failed states stretching from North Africa through the Balkans and the Middle East to South Asia. In addition, parts of Sub-Saharan Africa, East Asia, Central America, and the Caribbean have been the loci of state failure in recent decades. These failures have produced refugees, human rights abuses, inter- and intrastate wars, drug and human trafficking, and other problems that crossed international borders. ${ }^{39}$ After many years of intervention and civil war in Iraq, and mostly after the Iraq war in 2003, there were hopes for the establishment of the bases for a new stable democracy in different moments.

33 FUKUYAMA, Francis: Nation-Building 101, in: The Real State of the Union: From the Best Minds in America, Bold Solutions to the Problems Politicians Dare Not to Address, HALSTEAD, Ted (ed.), New York 2004, 250.

34 HOUT, Wil: Between Development and Security: the European Union, governance and fragile states, in: Third World Quarterly, 31, 2010, 1, 141.

35 ROTBERG, 2003, 4-6.

36 KRASNER, Abiding Sovereignty, 232.

37 BUEGER - BETHKE, 46.

38 IGNATIEFF.

39 Cited, FUKUYAMA, Francis: Nation-Building and the Failure of Institutional Memory, in: Nation-Building Beyond Afghanistan and Iraq, FUKUYAMA, Francis (ed.), Baltimore 2006, 2. 


\begin{tabular}{|c|c|c|}
\hline $\cos$ & 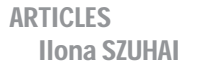 & 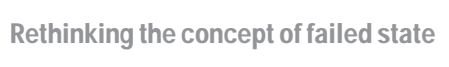 \\
\hline
\end{tabular}

The creation of interim local governments with the financial support of the international community - and specially the role of the US - during the past ten years created a hope among the international community for the evolution of the country towards a more stable and democratic regime. But currently the events that have taken place in Iraq mostly since 2003 are the evidence that Iraq is far from achieving this goal. Iraq is still currently involved in increased levels of sectarian violence. The American intervention in Iraq in 2003 and the more recent withdrawal of the international troops from the country have directly contributed to the crescent instability in the country. Achieving reconciliation within and between the different sectarian groups living in Iraq is missing..$^{40}$

The historical depth of the Iraqi challenge is grounded in prolonged state fragility that existed since Iraq's creation by Britain through a League of Nations mandate and was compounded by the collapse of the state following the invasion and subsequent occupation in $2003 .{ }^{41}$ The quick fixes imposed in Iraq (as elsewhere in the region) to meet the short-term interests of outsiders, rather than those of Iraqis, or longer-term requirements, permeated the initial stages of state formation and resonate in the prolonged instability of Iraq and the region. In consequence, as a fragile state, Iraq suffered enduring turmoil and violence in the form of both frequent regime change and regime policy. ${ }^{42}$ Measured against these criteria, pre-2003 Iraq was perhaps not yet a failed (or entirely collapsed, as Rotberg terms the most extreme cases of state failure) state, but certainly a fragile state on its way to failure. This was manifested perhaps most clearly in the prevalence of economic development that was uneven along communitarian lines; the criminalization of the state; the widespread violation of human rights; and a security apparatus operating as a state within the state. Building on his criteria, Rotberg himself had identified Iraq as belonging within a special category of fragile states: a seemingly strong, always autocratic state, which rigidly controls dissent and is thus itself secure, but provide few political goods. ${ }^{43}$ Acemoglu and Robinson has explained that aftermath of the US-led invasion the base of a real democracy was not created so a polarized situation was formed in Iraq, i.e. the inclusive institutional system was not established. Despite of the optimistic hopes about the future of Iraqi society and democracy, "these hopes were quickly dashed as chaos and civil war descended upon Iraqi society." That is why the Islamic State had a chance to win the loyalty of the people. ${ }^{44}$ In many territories which are under control of the Islamic State, the organisation provides basic public services so it functions as quasi government. "ISIS is holding territory and attempting to govern it [...] ISIS had established sufficient territorial control and governance over populations to feel confident enough to proclaim the Caliphate." 45

40 GARCIA, Ana: Reconciliation Processes in Iraq: The Potential of Truth Commissions to Bring Democracy, 2013, online: https://dl.tufts.edu/bookreader/tufts:UA015.012.081.00014\#page/1/mode/2up.

41 BOUILLON, Markus E.: Iraq's state-building enterprise: State fragility, state failure and a new social contract, in: International Journal of Contemporary Iraqi Studies, 6, 2012, 3, 281.

42 BOUILLON, 282.

43 BOUILLON, 285.

44 ACEMOGLU - ROBINSON, 444.

45 BYMAN, Daniel L. - HAMID, Shadi - LISTER, Charles - McCANTS, William - SHAPIRO, Jeremy: Around the Halls: What is ISIS' Strategy?, online: http://www.brookings.edu/blogs/iran-at-saban/posts/2014/09/24-aroundthe-halls-isis-strategy. 
It is worth watching how Iraq looks like today. Stephen O'Brien, the UN Emergency Relief Coordinator and Under-Secretary-General for Humanitarian Affairs, has recently reported that millions of people are in need of a greater assistance across Iraq. "It's imperative at this critical time we do more to mitigate the suffering of the Iraqi people. Much has been done, but the needs continue to increase and more is needed." The humanitarian situation in Iraq is dire. Since January 2014, more than three million Iraqis have been displaced from their homes and over eight million people are in need of assistance that aid agencies cannot always provide them with, due to lack of access or because of funding challenges. As fighting continues, the humanitarian situation will further deteriorate. To cover the most basic needs in Iraq, the UN urgently need \$ 497 million to provide shelter, food, water and other life-saving services over the coming six months. ${ }^{46}$

\section{Conclusion}

The terms of failed states, failing states, fragile states have come to be used in such widely divergent and problematic ways that they have lost any utility. The term of failed state is inadequate, even misleading, for virtually every country it purports to describe. ${ }^{47}$ The very concept of fragility is in development. Its heterogeneity and inherent multi-dimensionality have recently led some scholars to cluster countries in relatively differentiated fragility types. Hence, different alignments of fragility's dimensions - namely, the state's capacity, authority, and legitimacy levels - define these fragility types. Especially in contexts of fragility, analyses on the effectiveness of external support policies will become more relevant when additional information on specific policy combinations becomes available - such as the level of diplomatic pressure, the use of conditionality clauses in trade agreements, and the relative commitment to supporting civil society organizations. ${ }^{48}$

Fragile states that fall into protracted armed conflict almost always produce large refugee flows that pose considerable burdens on neighbouring states and that can become onerous political problems for third countries (mainly in the West) where refugees subsequently resettle in large numbers, legally or illegally. The political backlash against the influx of refugee/immigrant communities in some European countries has become a significant driver of European policy toward failed states. ${ }^{49}$ Today, the number of refugees reached a record number. This is reflected in António Guterres' critical words. The former High Commissioner for Refugees reported that around the world, almost sixty million have been displaced by conflict and persecution. Nearly twenty million of them are refugees, and more than half are children. Their numbers are growing and accelerating, every single day, on every continent. World stability is falling apart leaving a wake of displacement on an unprecedented scale. Global powers have become either passive observers or distant players in the conflicts driving so many innocent civilians from their homes. ${ }^{50}$

46 UN (2015), http://www.un.org/apps/news/story.asp?NewsID=51107\#.VYBt6UbdVB8.

47 CALL, 1491.

48 ZULUETA-FÜLSCHER, Kimana: Democracy-Support Effectiveness in Fragile States: A Review, in: International Studies Review, 16, 2014, 1, 43

49 MENKHAUS, Kenneth J.: State Fragility as a Wicked Problem, in: Prism, 1, 2008, 2, 95.

50 UNHCR, http://www.unhcr.org/558016eb6.html. 


\begin{tabular}{|c|c|c|}
\hline $\cos$ & 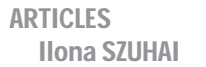 & 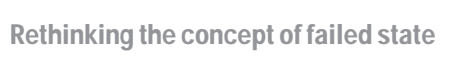 \\
\hline
\end{tabular}

Helman and Ratner's suggestion ${ }^{51}$ could be valid today. "The international community needs a cost-effective way to respond to growing national instability and human misery." It should be considered to strengthen weak states to combat internal threats of terrorism, insurgency and organized crime..$^{52}$ As growing anarchy spreads across the world, 2015 remained a turbulent year of conflicts which drew attention on instable, failing and failed states. Instability in governance and intrastate armed conflicts promote humanitarian crises. All of those generate one of the biggest global phenomena today, the forced migration. Preventing the instability of countries and state failure, with the view on development and aid operations needs strong political responsibility of world power. With Rotberg words "how best to strengthen weak states and prevent state failure are among the urgent questions of the twenty-first century." ${ }^{53}$

\begin{abstract}
This study summarises the history of failed state concept, the difficulties of a clear definition of failed state and the reasons why the categories of various linking expressions like weak, fragile, failing, collapsed states are mixing. 2015 remained a turbulent year of conflicts in the world, which drew attention on failed states. One of the symptoms of failed states is the form of forced migration when people leave their home due to intrastate armed conflicts, terrorist activities, brutal violation of human rights, poverty, lack of humanitarian aid and poor public services. The study outlines the connection with security and one of the biggest actual global phenomena, the mass refugee movements. That has become in the focus of the European discourse due to the humanitarian catastrophe in the Mediterranean. The current measurement of instable states is problematic which has strong impact on interventions and aid operations.
\end{abstract}

\title{
Keywords
}

Failed states, fragile state index, instable states, mass migration, Iraq

\section{References}

ACEMOGLU, Daron - ROBINSON, James A.: Why nations fail: The origins of power, prosperity, and poverty, New York 2012, 571.

A Secure Europe in a Better World. European Security Strategy. Brussels 12 December 2003. Online: https://www.consilium.europa.eu/uedocs/cmsUpload/78367.pdf.

BOUILLON, Markus E.: Iraq's state-building enterprise: State fragility, state failure and a new social contract, in: International Journal of Contemporary Iraqi Studies, 6, 2012, 3, 281-297.

BUEGER, Christian - BETHKE, Felix: Actor-networking the 'failed state' - an enquiry into the life of concepts, in: Journal of International Relations and Development, 17, 2014, 1, $30-60$.

51 HELMAN, Gerald B. - RATNER, Steven R.: Saving Failed States, in: Foreign Policy, no. 89, 1992-93, 20.

52 STEWART, 27.

53 ROTBERG, Robert I.: The Failure and Collapse of Nation-States, Breakdown, Prevention, and Repair, in: When States Fail, ROTBERG, Robert I. (ed.), Princeton 2003, 1. 
BYMAN, Daniel L. - HAMID, Shadi - LISTER, Charles - McCANTS, William - SHAPIRO, Jeremy: Around the Halls: What is ISIS' Strategy? online: http://www.brookings.edu/ blogs/iran-at-saban/posts/2014/09/24-around-the-halls-isis-strategy.

CALL, Charles T.: The Fallacy of the Failed State, in: Third World Quarterly, 29, 2008, 8, 1491-1507.

Di JOHN, Jonathan: Conceptualising the Causes and Consequences of Failed States, A Critical Review of the Literature, in: Crisis States Working Paper, Series 2, no. 25, 2008.

Di JOHN, Jonathan: The Concept, Causes and Consequences of Failed States: A Critical Review of the Literature and Agenda for Research with Specific Reference to Sub-Saharan Africa, in: European Journal of Development Research, 22, 2010, 1, 10-30.

EZROW, Natasha - FRANTZ, Erica: Revisiting the Concept of the Failed State: bringing the state back, in: Third World Quarterly, 34, 2013, 8, 1323-1338.

FUKUYAMA, Francis: Nation-Building 101, in: The Real State of the Union: From the Best Minds in America, Bold Solutions to the Problems Politicians Dare Not to Address, HALSTEAD, Ted (ed.), New York 2004, 250-262.

FUKUYAMA, Francis: Nation-Building and the Failure of Institutional Memory, in: Nation-Building Beyond Afghanistan and Iraq, FUKUYAMA, Francis (ed.), Baltimore 2006, $1-16$.

Fragile State Index, online: http://ffp.statesindex.org.

GARCIA, Ana: Reconciliation Processes in Iraq: The Potential of Truth Commissions to Bring Democracy, 2013, online: https://dl.tufts.edu/bookreader/tufts :UA015.012.081.00014\#page/1/mode/2up.

HELMAN, Gerald B. - RATNER, Steven R.: Saving Failed States, in: Foreign Policy, no. 89, 1992, 3-20.

HOUT, Wil: Between Development and Security: the European Union, governance and fragile states, in: Third World Quarterly, 31, 2010, 1, 141-157.

IGNATIEFF, Michael: The Burden, in: The New York Times, January 5, 2003, online: http:// www.nytimes.com/2003/01/05/magazine/05EMPIRE.html?pagewanted=all.

KRASNER, Stephen D.: Sovereignty, in: Foreign Policy, no. 122, 2001, 20-29.

KRASNER, Stephen D.: Abiding Sovereignty, in: International Political Science Review, 22, 2001, 3, 229-251.

MAZARR, Michael J.: The Rise and Fall of the Failed-State Paradigm, in: Foreign Affairs, 93, 2014, 1, online: http://www.foreignaffairs.com/articles/140347/michael-j-mazarr/ the-rise-and-fall-of-the-failed-state-paradigm.

MENKHAUS, Kenneth J.: State Fragility as a Wicked Problem, in: Prism, 1, 2008, 2, 85-100. NGUYEN, Minh: The question of 'failed states', Australia and the Notion of State Failure, in: View on Asia, 2005, online: http://www.uniya.org/research/state_failure.pdf.

PUTZEL, James - Di JOHN, Jonathan: Meeting the challenges of Crisis States. Crisis States Research Centre report, London 2012.

ROTBERG, Robert I.: Failed States in a World of Terror, in: Foreign Affairs, 81, 2002, $4,1-13$.

ROTBERG, Robert I.: Failed States, Collapsed States, Weak States: Causes and Indicators, in: State Failure and State Weakness in a Time of Terror, ROTBERG, RobertI. (ed.), Washington 2003, 1-25.

ROTBERG, Robert I.: The Failure and Collapse of Nation-States, Breakdown, Prevention, and Repair, in: When States Fail, ROTBERG, Robert I. (ed.), Princeton 2003, 1-50. 
SEDRA, Mark: Finding Innovation in State-Building: Moving Beyond the Orthodox Liberal Model, in: Prism, 3, 2012, 3, 47-62.

STEWART, Patrick: Weak States and Global Threats: Fact or Fiction? in: The Washington Quarterly, 29, 2006, 2, 27-53.

UN: http://www.un.org/apps/news/story.asp?NewsID=51107\#.VYBt6UbdVB8.

UNHCR: http://www.unhcr.org/558016eb6.html.

ZARTMAN, William I.: Introduction: Posing the Problem of State Collapse, in: Collapsed States: The Disintegration and Restoration of Legitimate Authority, ZARTMAN, William I. (ed.), Boulder 1995, 1-11.

ZULUETA-FÜLSCHER, Kimana: Democracy-Support Effectiveness in Fragile States: A Review, in: International Studies Review, 16, 2014, 1, 29-49. 